\title{
The Roots of Fencing from the Twelfth to the Fourteenth Centuries in the French Language Area
}

Olivier Dupuis, independent researcher, dupuisolivier@yahoo.fr

Abstract-This article offers a partial overview on fencing, as recognized through archive records, as well as French epics and romances from the twelfth to the early fourteenth century. In the twelfth century, fencing was only attested through knightly vocabulary as a way to describe actions performed during single combats involving a combination of shield and another weapon, most commonly a sword. Fencing was progressively dissociated from the knightly arts and there were even few mentions of its use by common people. There are archive records from the thirteenth century of individuals bearing the nickname "fencer", although there is rarely enough context to be certain that they were really practicing the art. At the end of the thirteenth century, archives and narrative fiction show an established fashion for a certain form of fencing with a short round shield, the buckler. This is clearly established in London where surviving manuscripts include many regulations on fencing, however the fashion was also spread in the continent, even though it seems to be less documented.

Keywords - fencing, France, twelfth century, thirteenth century

\section{INTRODUCTION}

Some form of martial arts undoubtedly existed through the entire Middle Ages. During the twelfth century vernacular words appeared, dedicated to a subset of this art: "escremie" in Old French or "schirmen" in Old German. This did not occurred on its own, for the vernaculars were accompanied by a small series of technical terms related to specific actions of fencing. During the thirteenth century, certain words referring to practitioners of this art emerged. Sydney Anglo gave us an enlightening overview of the first appearance of those terms. ${ }^{1}$ A recent article from Rachel Kellett shows how much light such a study in German literature can shed on the study of early fencing manuals. ${ }^{2}$ In this article, I shall focus on Old French literature.

1 Sydney Anglo, Martial Arts of Renaissance Europe (New Haven: Yale University Press, 2000) p. 7-8.

2 Rachel E Kellett. "Royal Armouries Ms I.33: The Judicial Combat and the Art of Fencing in Thirteenth- and Fourteenth-century German Literature", Oxford German Studies 41-1 (2013), pp. 34-41. 


\section{FENCING IN THE OLD FRENCH VOCABULARY}

\section{II.1. Apparition of the word "escremie"}

Following the dictionary of Tobler-Lommatzsch, the verb "escrimir" appeared first around year 1100. It is derived - like the German "schirmen" - from an Old Franconian word, "skirmjan", which meant "to defend" or "protect oneself". Sometimes "escrimir" took this meaning: "To the mother of God [he] prays and worships, to recover and aid Renart and protect him from deception, that in the battle he would not perish." 4

However the general meaning of "escrimir" was "to fight" which is the opposite of the original meaning. Probably it took a long time for it to complete the transition from "to defend oneself" to "to fight against another", as seen in the Romance of Eneas, around 1160: "A l'escremir sont revenu" ${ }^{5}$ ("They came back fighting"), or in Protheselaus before 1191: "D'eskermer ad grant talent."' ("he is very talented at fighting").

In the twelfth century texts "escrimir" seems to be exclusively used to refer to fighting sequences with the combination of a sword or a mace and a shield, on horseback or on the ground. I have not found any example of the term being used for spear fighting but this would require further study.

It is interesting to see the appearance of the neologism "escremie" during the twelfth century. Technically, "escremie" is a derivative form from the verb "escremir", but was used in a much wider sense than the verb. Naturally, as "escremir" meant to fight, "escremie" had been used as an equivalent to a combat:

Quand il sont venu a l'escremie (When they came to fight)

Aprés li conte de l'escremie que cil dou reaume de Norgales devoient faire encontre cez. dou reaume de Logres (After the story of the fight that those from the realm of Norgales had to do against those from the realm of Logres.... $)^{7}$

Neither was the passage from the verb to the noun a coincidence. Perhaps it indicates that fencing was at that time a system already homogeneous enough to be granted a

3 This word spread in many European languages. For a short overview, see Moritz Goldschmidt, 'Bruckner, Wilh., Charakteristik der germanischen Elemente im Italienischen', Zeitschrift für romanische Philologie, 24 (1900), p. 577.

4 "A damlede prie et aore / Que Renart garisse et secore / Et de mal engin l'escremisse / Qu'en la bataille ne perisse". Le Roman de Renart, ed. by Martin, vol. 1 (Strasbourg: K. J. Trübner, 1882) p. 222 branch VI v.913-6.

5 Eneas, ed. by Salverda de Grave J. (Halle a.S.: Niemeyer, 1891), p. 361 v.9 727.

6 Hue de Rotelande, Protheselaus, ed. by Holden A. J. (London: Anglo-Normand Text Society, 1991), vol.1 p. 87 v.3163.

7 These two extracts comes from the mid-thirteenth century text Le roman de Tristan en prose, éd. Curtis Renée, vol. 2 (Leiden: Brill, 1976) p. 193 \$609 and p. 199 \$616. 
specific name. The word had many other meanings. For example the "escremie" was used as a generic category of actions that could be done in a combat: "Geter de boins cops d'escremie" ("To throw good fencing blows") 8 or in a more subtle meaning "E plusurs jus comencer funt / D'eskermies e de palestes" ("And [they] began many games of fights and wrestling").?

By extension, the term began to denote a subset of the martial arts which soon took the role of the modern word of fencing. There was a transition from the knowledge required to fence ("D'eskermir ad grant talent", quoted above), to the notion of the knowledge of fencing: "qui plus set de l'escremie" ("who is more acknowledged in fencing"). ${ }^{10}$

The character Perceval le Gallois from Chrétien de Troyes received an education in chivalry later in his life, after having left his home. He first learned how to manage both spear and horse, after which his master asked him what he should do if he happened to lose his spear. Perceval answered that he would have to use his fists. The master corrected him by explaining that such a situation would require sword fencing. Perceval replied that he learned enough of that stuff when he lived with his mother, where he practiced with a bag and a shield ${ }^{11}$. This curious passage is interesting in two ways. First it gives rare information about the use of some sort of a punching bag as a learning tool, but also that fencing itself was not something specific to the knights anymore; it could be learned independently and almost alone, at least for someone naturally gifted like Perceval.

Most of the time, fencing as practical knowledge required specific training. Some mention of such teaching can be found in the period romantic literature. For example, we may learn that Hervis of Metz "was well educated at fencing". ${ }^{12}$ This was another way to tell that a knight was skilled, but what is remarkable is that the expression provides a case for learning, not only an inborn talent. ${ }^{13}$ To confirm that, later in the

8 Perceval le Gallois ou le Conte du Graal, ed. Potvin Ch. (Mons: Dequesne-Masquillier, 1866-1871), vol. 3 v.13184 p. 143, around 1180-1190.

9 Tristan, ed. by Michel F. (Paris: Techener, 1835), p. 38, v.798-9, last third of the twelfth century.

10 Le roman de Tristan en prose, p. $76 \$ 462$.

11 "Par escremie / del espée l'irés requerre". Perceval v.2710-11. And later "De ce, fait-il, se Dex me saut / Ne set nus tant come je fac / Qu'ès bouriaus et as talevas / Ciés ma mère, en apris assés”, v.2122-25.

12 "A l'acremie, bien fut doctrinez". Hervis de Mes, Chanson de Geste Anonyme, ed. by Herbin J.-C. (Genève: Droz, 1992), p. 73, v.1627, before 1215.

13 For example, an inherited talent, Beton, the nephew of Charlemagne learns how to fence, joust and carry the weapons in only one year. See Daurel et Beton, chanson de geste provençale, ed. Didot M. A., Meyer Paul (Paris: Firmin Didot, 1880), p. 54 c. 1200: “.I. an lo tenc que re no ac que dir / E sap d'escrima, de garnimens tenir'. 
same song, two high-ranking knights were also granted such training as a proof of their value. $^{14}$

For those devoted to knightly service, such training was received during one's youth, as was clearly noted in Le Couronnement de Louis or in Raoul of Cambrai. ${ }^{15}$ This was confirmed in $Y$ de et Olive, a later work from the end of the thirteenth century, which describes some children practicing fencing after the banquet. ${ }^{16}$ Sometimes, the age where this training was received is mentioned, as in the song Escoufle, where Guillaume de Montivilliers is said to have learned fencing from a master before the age of ten years. ${ }^{17}$ This is consistent with the fictional history of Beton, who began to learn fencing at the age of eleven. Here the teacher was known for being his tutor, the juggler Daurel. This is interesting, as Daurel was not a knight, but had enough knowledge not only to manage the teaching, but also to face his pupil in combat when the latter was twelve years old. ${ }^{18}$

Apart from narrative literature quotes, Anglo mentioned that in 1220 a certain "Walter de Stewton was charged with murder and learned fencing ('et discer eskirmire') in readiness for the combat", which proved that this could also be learned by an adult having nothing to do with chivalry. ${ }^{19}$ In the same year, Elias Piggun testified before the court of Cheshunt that he gave fencing lessons some years ago to a man who then paid him with some pigs and a mare. This appears to have been a false testimony, probably done to report the accusation of theft of the mare from the real thief to Elias Piggun. It seems that Elias wanted to intimidate the prosecution who might have been afraid to fight a judicial duel against a fencing master. ${ }^{20}$

It is clear that at the beginning of the thirteenth century, the practice of fencing went beyond the strict limits of the knightly arts, at least in the French speaking countries.

14 “De l'acremie fut chascuns doctrinez". Hervis de Mes, p. 260 v.6123.

15 "De l'escremir s'est bien aparelliés, / Car en s'enfance detereciés en fu bien”. Le couronnement de Louis, chanson de geste du XIIe siècle, ed. by Ernest Langlois, 2nd ed., Les classiques français du Moyen Âge 22 (Paris: Champion, 1925), p. 148 v.6-8, dated from the middle of the twelfth century. "Quand Raous fu jovenciax a Paris / A escrimir ot as effans apris". Raoul de Cambrai, ed. by Meyer P., Longnon A. (Paris: Firmin Didot, 1882) p. 98 v.2854-2856. Around 1200.

16 "Après mengier se jüent li auquant / A escremir aprendent li enfant / Et li plusiour vont as tables juant". Esclarmonde, Clarisse et Florent, Yde et Olive: drei Fortsetzungen der Chanson von Huon de Bordeaux, ed. by Max Schweigel (Marburg: Elwert, 1889), p. 152 v.6203-05.

17 Jean Renart, L'Escoufle, roman d'aventure, ed. by Sweetser Franklin (Genève: Droz, 1974), p. 61, c.1200. The interesting passage is between "Li damoisiax avoit .j. mestre / ki li aprent de l'escremie" v. 2018-2019 until "Et quand Guilliaumes ot .x. ans", v.2040.

18 "Quant ac .xj. ans el se sap escrimir". Daurel et Beton, p. 53, v. 1578. For the jousting between Daurel and Beton, see v. 1600-40 pp. 54-55.

19 Anglo, Martial Arts..., p. 7.

20 Richard Firth Green, Literature and Law', in A companion to Medieval English Literature and Culture c.1350-c.1500, ed. by Peter Brown (Malden, MA: Wiley-Blackwell, 2009) pp. 301-02. 


\section{II.2. Fencing technical words from French literature}

In 2006 at the HEMAC event in Dijon, Matthew Galas gave a lecture on the fencing terminology found in French songs of heroic deeds. He described a broad range of terminology devoted to fencing in Old French literature from the twelfth to the fourteenth centuries ${ }^{21}$. Some of these words could not really be considered technical, as they did not take a distinct meaning when used in a context of fencing in regard to their use in the common language. For example "couvrir" or "ganchir" which meant respectively 'to cover' and 'to avoid'. However, some of these words were undoubtedly technical words which took on a specific meaning in the context of fencing. ${ }^{22}$ Some of them have been used as fencing terms at least since the nineteenth century. ${ }^{23}$ It is beyond the scope of this paper to produce a complete vocabulary of all of those terms, however, we can examine a representative set of technical words ("arriere main", "entredeus", "entorcief", "se mouler", "retraite", "souspane", "sormontee", "traverse", "treget") with the textual context of their use, and if possible, attempt an interpretation. However, the form of the poems and texts where these words appeared is not descriptive by far, thus it is often impossible to have a proper definition. I can also attempt to suggest the date of the terminology, even if it proves to be very difficult: the majority of texts do not have an accurate dating.

One can make a few remarks about these technical words. Two of them are neologisms, "entorcief" and "souspane". One is a combination of a word and an adjective (called a "synapsy" in linguistics): "arriere main". The others are homonyms of common words that took a specific sense when used to describe a fight. Those terms are concise and were very well adapted to the rhymed poems where they first appeared. Could it be possible that they are only embellishments or neologisms created by the jugglers to better describe fights? It is possible that this might be the case for one or two of the studied words. However, it is dubious, as a significant part of the audience of these songs or poems would have been skilled in different fighting arts and it is unlikely they would have appreciated such inventions. Nevertheless, it is very likely that their insertion into these works supported their wider propagation throughout the Old French languages.

With the exception of "arriere main", these technical words disappeared from the Old French texts before the end of the fourteenth century and were replaced by a new

21 The list of the words presented by M. Galas can be found in Fabrice Cognot, 'L'armement médiéval, les armes blanches dans les collections bourguignonnes, Xe-XVe siècles', (unpublished doctoral thesis, University Paris 1 Panthéon-Sorbonne, 2013), p. 124 footnote 275.

22 For a more complete study about technical words, see Marie-Françoise Mortureux, "Les vocabulaires scientifiques et techniques", Les Carnets du Cediscor, 3 (1995), pp. 13-25.

23 "moller [...] ist ein Term. techn. für Kämpfende [...] treget [...] ist ein Fectherausdruck (wie entredeus, retraite, sormontée, trauersaine)". W. Förster, 'Recensionen und anzeigen, Maistre Wace's Roman de Rou et des Ducs de Normandie', Zeitschrift für romanische Philologie, 1 (1877), p. 151. 
vocabulary, as for example the word "rabat" which refers to the action of pulling down the opponent's weapon as a defensive action. Another example was the thrust, "estoc" which was first a generic word to refer to the point of an object and a "coup d'estoc" was literally the blow given with the point of the weapon. As it seems, the word "estoc" was used only after the second part of the fourteenth century ${ }^{24}$. However, the evolution of this technical vocabulary requires study that would take us beyond the scope of this paper.

\section{II.2.1. "Atriere main"}

The "arriere main" is basically a reverse cut. This term is not only a fencing word, and it appeared concurrently to refer to a reverse strike. It literally meant 'back-hand' and could be used in many other contexts like playing dice or in ball games.

The term appeared in the first half of the thirteenth century, an example can be found in the "Tournoiement Antechrist" (circa 1230) where the allegory of Luck made "a reverse cut using a club with 18 points" 25 . It was also used by Joinville in 1309 when he told that: "At the moment when the Saracen passed, my lord John gave him a back-hand cut with a sword on the arm"26.

\section{II.2.2. "Entorcief"}

An "entorcief" was most probably a cut given by passing the weapon around the head. It is not clear if it was a reverse or a direct cut. It could even be both. I was only able to find one reference to this word in one manuscript from the thirteenth century, Cristal et Clarie, in the following sentence: "He knows to throw all type of hits. He throws an around-the-head cut and then moves forward with the left foot and throws him a crossing cut." 27

\section{II.2.3. "Entredeus"}

This word is very common in the songs of heroic deeds and means literally "inbetween". It probably referred to a blow driven between the sword and the shield of the opponent. This seems more likely to refer to the way it was executed that to the fact it succeeded to pass between the sword and the shield. For example, in the novel of Protheselaus, the hero touched the eye of his opponent with an in-between strike that

\footnotetext{
24 See the entries "rabat" and "estoc" in the dictionary of Godefroy.

25 "Qu'el' fiert Hasart arière main / D'un gibet de .XVIII. poins". Huon de Méry, Le Tournoiement de l'Antéchrist, ed. by Tarbé. P. (Reims: P. Regnier, 1851), p. 66.

26 Joinville, la vie de Saint-Louis, p.272 \550: “Au passer que le Sarrazin fist, mon seigneur. Jeban li donna ariere main d'une espee parmi le bras".

27 "Il sot tos les cops geter / un entorkief lor a geté / del piet senestre avant passé / une traverse li porta". See Leo Jordan, Über den alffranzösischen Abenteuerroman "Cristal et Clarie” (Bonn: Georgi, 1899), p. 31 v. 4810-14.
} 
that was partially parried by the shield ("D'un entredous dedenz l'escu"). His opponent contested the hit and pretended that he hit himself with his shield. ${ }^{28}$

For a good overview of the full range of its use, a large amount of examples offered by the Tobler or the Godefroy dictionaries is sufficient. Some extracts from the second half of the twelfth century follow below:

Turnus gave an in-between ${ }^{29}$

He knows how to cover and to mold himself with the shield, put the right foot forward and to double in-between ${ }^{30}$

[Renart] knows how to cover himself from the in-between, and how to hit for uncovering his companion ${ }^{31}$

Renart, who knows how to fence and to throw well an in-between, hits Roenel between the eyes. ${ }^{32}$

This last extract is the second example in which the in-between reached the eyes, which could point out more a thrust than a cut.

\section{II.2.4. "Se mouler"}

This meant to mold oneself inside a curved shield. This is not exactly a fencing term, but it is a technical term used to describe the way to hold the shield in preparation of the fight.

He puts [his shield] at his neck. He knows quite well to mold himself in it $^{33}$

[Renart] takes his shield and molds himself. ${ }^{34}$

28 Hue de Rotelande, p. 89 v.3185-94.

29 "Un entredeus porta Turnus". Eneas, ed. by Salverda de Grave, 1891, p. 363 v. 9731, dated from 1160.

30 Maistre Wace's Roman de Rou et des ducs de Normandie, ed. by Andresen, vol. 1 (Heibronn: Henninger, 1877), p. 103 v. 1770-71 of the part II: "As taleuaz se sout e cuurir et moller / Metre pied destre avant e entredous dubler".

31 "de l'entredous se set courir / et bien taper por descourir / son conpaignon". Le Roman de Renart, vol. 1, p. 220, branch VI, v. 837-9.

32 "Renart, qui bien sout escrimir / Et bien sout jeter entredeus / Fiert Roenel enmi les euz". Le Roman de Renart, ed. by Martin, vol. 2 (Strasbourg: K. J. Trübner, 1885), p. 104 branch XIII, v.2196.

33 " $L i$ dus a fait son escu aporter, Au col le met / moult bien s'i sot moler". Gaydon, ed. by Guessard F., Luce S. (Paris: Franck, 1862), p. 267 v. 8856-57.

34 "son escu prent et puis se mole". Roman de Renart, vol. 1, p. 228 branch VI, v.1115. 


\section{II.2.5. "Retraite"}

This blow was mostly used in conjunction with the word "coup", forming the synapsy "coup de retraite", literally "withdrawal blow". As the word "entredeus" presented before, its use was quite common in the context of duels. But this does not lift all the uncertainty as Trolli exposed very well. ${ }^{35}$ The expression could be understood in two possible ways, at least: either it could be a cut given while moving back, or a cut executed by withdrawing the blade. There is a third interpretation: as "traire l'espee" meant to draw the sword out of its sheath, a withdrawal cut could mean to perform a cut as one draws the sword out of the sheath. This impression is confirmed by the following extract from Protheselaus, where Hercules gives a "retraite" and literally draws his stick behind the opponent's shield, and while not able to touch the opponent, this successful execution makes Protheselaus feel ashamed. ${ }^{36}$ The following extract from the Roman d'Alexandre, circa 1180 , shows what seems to be a similar but successful action:

But he counters the sword with the shield put forward / Aristes throws such a withdrawal cut at him again / that he cut into his arm bone. ${ }^{37}$

The following extract supports the suggestion that this cut may not necessarily be realized with a backward footwork, as it could be executed on a horse. The Count Guillaume had a sword, his opponent was probably wielding a spear:

Aenrons comes, turns the shield forward. The count sees him coming in haste. He manages wisely to let him joust first and during his withdrawal gave him a much valuable blow at the neck. ${ }^{38}$

The following passage confirms that this blow could be aimed at the upper part of the body:

Li fet des Romains, 1214: "Then Antoines threw at him a withdrawal cut and hit him in the middle of the face" 39

35 Domizio Trolli, Parole del Boiardo. Sul lessico e il testo dell'Inamoramento de Orlando', in Studi di storia della lingua italiana offerti a Ghino Ghinassi, ed. by Bongrani Paolo et al. (Firenze: Le Lettere, 2001), pp. 123-35.

36 "Herculés a une retraite / Dedenz l'escu la verge ad traite / Il n'i traist sanc n’il n'i tucha / Proteselaüs bunte en a". Hue de Rotelande, Protheselaus, vol. 1, p. 89 v. 3179-82.

37 "Mais il contre le branc a l'escu avant trait / Aristes li regiete un tel cop de retrait / Que lo's de l' bras li trence [...]”. Alexandriade ou chanson de geste d'Alexandre-le-Grand, ed. by Le Court de la Villethassetz F., Talbot Eugène (Paris: Durand, 1861) p. 54, v.288-89.

38 "Vient Aenrons, l'escu devant torné / Li quens le voit venir tot abrivé / Il fist que sages, premerain a josté / A la retraite li a un cop doné / Molt avenant, el col l'a assené". Aliscans, ed. by Wienbeck Erich et al. (Halle a.S.: Niemeyer, 1903) p. 65 v.1032-3 d-h.

39 "Lors li gita Antoines un cop de retrete et le feri en mi le vis". Li fet des Romains compilé ensemble de Saluste et de Suetoine et de Lucan, ed. by Flutre L.-F. (Paris: Droz, 1935), 1, p. 532. 
The last extract is from the Roman de Renart, which mentiones a movement forward which is incompatible with a back-ward move: "YYsengrin] put the foot forward, throw a withdrawal" 40 .

\section{II.2.6. "Pene", "Sorpene", "souspane"}

These words appear in descriptions of fights, but rarely in situations that can help us understand their meaning. The dictionary of Godefroy gives a handful of examples of blows given above, under or on the "panne" of the shield. However, it offers a definition of "panne": the leather that covers the shield, which does not really make sense. For "penne" the same dictionary provides a definition of a point or a ridge, and I am more inclined to see in "panne" either a generic word to refer to one of the points of the shield, or its borders. In such a context, a blow called a "pene", "soupene", literally under"pane", or "surpene", literally over-"pane" can be understood as a blow aiming at, respectively, the border, under the border and over the border of the shield. For the following extract, I decided arbitrarily to translate "pane" as ridge.

And they throw blows shrewdly, and form ridges, withdrawals and overcomings. ${ }^{41}$

Nabor wants to show to the people that he is not apprentice, aims above and then throws below under the ridge..$^{42}$

"Sorpene" was only mentioned in one source, included in a long list of different blows:

They gave one another blows very shrewdly, to the arm, head and neck, withdrawals and above-the-ridge, overcoming and in-between, in such a way that one cannot see anything else but naked blades between them. ${ }^{43}$

It seems that this word is not correct, as other editions of manuscripts from the same work prefer to describe 'under the ridge'. ${ }^{44}$

40 Roman de Renart, vol. 1, p. 230 branch VI, v.1211: "Met pié avant, jete retrete".

41 "Et jectent d'escermie menuement, / Et penes et retraites, sormontées forment". La chevalerie Ogier de Danemarche par Raimbert de Paris, ed. by Barrois J. (Paris: Techener, 1842), vol. 2, p. 482, v. 11537-38, c.1200.

42 "[Nabor]veust mostrer au pueple qu'il n'est mie aprentiz, esme en haut et puis giete bas soz, penne". Le roman de Tristan en prose, p. 193, $\$ 609$.

43 "Molt menuement s'entredonent / Par bras, par testes et par cous / Retraites, sorpenes, et cous, / Sormontées, et entredeus / Si qu'on ne pooit entre eus deus / Veoir que les espées nues." Huon de Méry, Le Tournoiement de l'Antéchrist, p. 74.

44 May Plouzeau, 'Critique des éditions du roman des Eles et du Songe d'Enfer', in La structure de la proposition dans les langues romanes, ed. by Rouveret Alain, Sauzet Patrick (Revue des Langues Romanes, 93-1 (1989)) p. 462. 
It is worth noticing that the verb "souspanner" also existed which was used in the context of a fight in the meaning of temporizing or suspending. It is impossible to determine whether it is connected to the previous words or is it a derivate form of "souspence", to suspend. ${ }^{45}$

\section{II.2.7. "Sormontée"}

The word "sormontée" appeared many times in the enumerations of blows given during a fight, beside "entredeus" or "retraite". It can be translated literally as 'an overcoming'. An excerpt from a thirteenth century text gives a short description of a fight against an opponent who personified drunkenness:

And I 'tresgete', and he overcomes. He hits so hard that I feel dizzy in my head. This is the blow of overcoming, because it comes up to my head. ${ }^{46}$

This seems to be a hammering blow for someone wearing a helmet in the beginning of the thirteenth century. Probably it is a blow aiming at the top of the head and coming from above.

\section{II.2.8. "Traverse", “traversaine"}

Meaning literally "a crossover", this was used beside the word "blow", for example by Roman of Alexander during a fight on horses ("And so many crossing blows, so many other straight"), or alone as in Cristal et Clarie $e^{47}$. There is a clear opposition here to the straight blow ("droiturier"), and the "traverse" should certainly be understood as a blow crossing the line between the two fighters. This hypothesis is reinforced by the following quote from the translation by Jean de Meung of Vegecius from 1284: "To bend the javelins that one throws and to reroute it by crossing cuts". 48

45 Le roman de Laurin, ed. by Thorpe Lewis (Cambridge: Heffer, 1958) pp. 50, 165 and 276.

46 "Et je tresgète, et il sormonte / Si me fiert que el chief me monte / Où l'estormie m'est montée / Ce fu li cops de sormontée / Quar il me monte en la teste". Raoul de Houdenc, Le songe d'enfer suivi de la Voie de paradis, ed. by Lebesgue Phileas (Paris: Sansot \& Cie, 1908), p. 67 v. 269-73, c.1215.

47 "Et tant cop traversain, maint autre droiturier". Alexandriade, p. 184 v. 1457. For the extract of Cristal et Clarie, see above the note 27.

48 "flechir et destourber par cops traversains les gavelos que on gette". L'art de chevalerie, traduction du De re militari de Végèce par Jean de Meun, ed. by Robert Ulysse, (Paris: Firmin Didot, 1897) p. 9, writen in 1284. 
This word was used until the fourteenth century, with a similar meaning:

Ponthus was waiting to hit the pagan at his face, which was uncovered. And he threw him such crossover that he cut his nose, mouth and chin. $^{49}$

\section{II.2.9. 2 "Treget"}

This is the last technical word to be presented, and probably the one with the most uncertain meaning. A very clear excerpt proves that it could take the meaning of a blow:

To project to the left and to throw soon 'treget', this is a dangerous blow for those who do not know how to defend against. ${ }^{50}$

Following the study of Förster, "tregel" or all of its other forms, "tresgiet", "trasgitare", ... could take othermeanings, more commonplace at that time: a throw to the side, a spell or a magic trick, but also something molded. ${ }^{51}$ The combination of the step to the left, the feeling of dodging and throwing to the side can resemble the action of twisting the hand carrying the sword to give a cut with the back edge of the blade. But this is largely speculative.

The verb "tresgeter" was also used in context of fights or single combats but it is not clear whether it means 'to move' or 'to deliver a blow'. For example, in Protheselaus, a protagonist "begins to throw all the blows, and to magnificently 'tresgeter". ${ }^{2}$

\section{FENCERS AND FENCING MASTERS IN THE THIRTEENTH AND EARLY FOURTEENTH CENTURIES}

\section{III.1. Fencers}

The "escrimisseur", literally "a fencer" is a word that derived naturally from the word "escrimie", and appears at the end of the twelfth century. It took many different forms depending on the geographical region where it was used: "skirmissor" in AngloNormandy, "eskermisoir" in Picard or Walloon districts, "escrimaor" in Franco-Italian regions, and probably many other vernacular forms. ${ }^{53}$

49 "Tousjours Ponthus estoit en aguet de ferir le payen par le visage qui estoit descouvert, et tant qu'il va gecter une traverse tellement qu'il lui couppa tout le nez et la bouche et le menton." Le roman de Ponthus et Sidoine, ed. by Marie-Claude de Crécy (Genève: Droz, 1997), p. 27.

50 "Saillir deuers senestre e treget tost geter / C'est uns cols damagus, ki ne s'en set garder". Maistre Wace's Roman de Rou, vol. 1, p. 103, v.1773-74.

51 Förster, Recensionen und anzeigen, ...', p. 151.

52 “Tuz les cops comence a jeter / E a mervaille tresgeter." Hue de Rotelande, p. 89 v.3197-98.

53 For example in Anglo-Normand, the following form have been listed by Lewis and Reidy in their Middle English Dictionary: "skirmesour", "skirmesur", "skirmisour", "skirmishour", "scrimissur", 
One of the oldest mentions, "eskermisor", is found in the Romance of Protheslaus at the end of the twelfth century, where the spectators of the single combat react after a good blow: "See what produces the fencer, no one is born in this life who knows more from fencing." 54 Approximately at the same time, two charters from 1182 and 1190 showed that three individuals in Aubigny-en-Artois carried the surname of "li Escremissieres". Jean li Escremissieres was a cleric, Hugo li Escremissieres and Jean Escremiscieres were deputy majors from the town. Here "Escremissieres" seemed to have been a family name. ${ }^{55} \mathrm{~A}$ few years later in England, a Radulfus the Schermisur (1197) and Gaufridus le Skermesur (1201) were mentioned in archive documents. ${ }^{56}$ However, in both cases, there is nothing in the context that could assert that they really were fencers. The first case, Radulfus appeared in an account register, in the second Gaufridus appeared in a recorded oath about some land.

A fencer was supposed to be a man who knew how to fence or who practiced it. In the thirteenth century it probably meant that he does not have any better qualification than thas one: he is not a knight or any other man-at-arms, he is also not a champion, which is only a temporary state. For example, in his youth, the narrative hero Sone de Nansay, was said to be a good fencer. ${ }^{57}$ This is also quite clear in the following extract: "if Tristan was the best knight in the world, Nabon the Black was the best fencer in the world." 58 This confirms, if necessary, that at that time there was a clear distinction between fencing skills and all other abilities required of a knight.

"shirmisur", "skermesur", "schemisur". Other examples in Wallon and Picard: "eskermisoir", "eskermisseur", "eskermixhere", "eskermixheur". Raoul Van Der Made, Inventaire analytique et chronologique du chartrier des Guillemins de Liège, 1317-1669 (Bruxelles: Palais des académies, 1955), p. 299. The Franco-Italian "escrimaor" appeared in L'entree d'Espagne, chanson de geste franco-italienne publiée d'après le manuscrit unique de Venise, ed. by Thomas Antoine, 1 (Paris: Firmin-Didot, 1913), p. 156 v.4259.

54 "eez delivre eskermisor! / Unc ne nasqui en ceste vie / Qui plus seüst de l'eskermie." Hue de Rotelande, v. 3200-04, p. 90.

55 Les chartes des comtes de Saint-Pol (XIe-XIIIe siècles), ed. by Jean-François Nieus (Turnhout: Brepols, 2008), p. 144-45 charter number 58 and p. 161 charter number 76.

56 "Radulfus le Schermisur debet dim. m. quia retraxit se." The Great Roll of the Pipe for the ninth year of the reign of King Richard the first Michaelmas 1197, ed. by Doris M. Stenton (London: Pipe Roll Society, 1931) p. 86. "Jurata inter Gaufridum Marescallum petentem et Gaufridum le Eschermisur de j. virgata terre cum pertinenciis in Stapelton..." Curia Regis Rolls Preserved in the Public Record Office, 14 (1971) p. 134.

57 "Escremissieres iert mout byaus." Sone von Nausay, ed. by Moritz Goldschmidt (Tübingen: Litterarischer Verein in Stuttgart, 1899), p. 3 v.92.

58 "comme Tristan est le meilleur cheualier du monde, aussi est Nabon le noir le meilleur escremisseur du monde." Alexander Nicolaevich Vieselovskiy, Iz Istorii Romana i Povesti: Materijali i Isledovanija, vol. 2, (Saint Petersburg: Academy of Science, 1888), p. 197. 
Among many historians, Daressy asserted that those qualifications were referring to a fencing master ${ }^{59}$. This could be true in particular cases, but in general, it suggests that a good fencer is a fencing master. I propose to study in detail the example of the occurrences of "escrimisseeur" that appeared in tax rolls from Paris around 1300.

\section{III.2. The "escrimisseur" from Paris}

There is a handful of surviving Tax Rolls in the Paris register. But they do not have the same meaning. The older, and probably most famous, was a census of the population made in 1292 to estimate the taxable capability of a large part of the city. This is not a complete census, as a large part of the left side of the Seine was under the jurisdiction of different religious communities in regard to collecting tax. The city of Paris negotiated the imposition of an exceptional tax for eight consecutive years. The surviving records consist of five tax roll books from 1296-1300, the first three were lost. Finally, in 1313 the King of France levied an exceptional tax to cover the costs of his son entering a chivalric order ${ }^{60}$. Only four of these seven registers have survived for the years 1292, 1296, 1297 and 131361. Each document is divided by parish and street, and records what has been paid or - for the year 1292 - what could be paid. Some people were exempted, for example the noblemen; people too poor to pay anything were not recorded.

Within these records, there are seven people with the word "escremisseur" written next to their fornames. ${ }^{62}$

Guillaume l'escremisseeur was only mentioned in the tax roll from 1292, but he is probably the same person who appeared two times in the daily details of expenditure of the Royal Hotel, the fourteenth of November 1285 and the tenth of January 1286 Guillelmus l'Escrimisse or l'Escrimisseeur. ${ }^{63} \mathrm{He}$ also appeared in the accounts of bailiffs

59 "Le nom d'escrémisséeur, de scremisseeur, etc., était donné aux maîtres d'armes", Henri Daressy, Archives des maittres d'armes de Paris (Paris: maison Quantin, 1888) p. 128.

60 Le Livre de la taille de Paris, l'an 1296, ed. by Karl Michaëlsson (Göteborg: Elanders boktryck, 1956), p. iii-iv.

61 For the year 1292, see Hercule Géraud, Paris sous Philippe-le-Bel, 1837. The others have been edited by Karl Michaëlsson, Le Livre de la taille de Paris, l'an 1296, Le Livre de la taille de Paris, l'an 1297 (Göteborg: Elanders boktryck, 1962) and Le Livre de la taille de Paris, l'an de grace 1313 (Göteborg: Wettergren \& Kerbers förlag, 1951).

62 Géraud, Paris sous Philippe-le-Bel, p. 13, 38, 69, 112, 141, 151 and 154. Le Livre de la taille de Paris, ed. by Michaëlsson, l'an 1296, p. 62 and 168. Le Livre de la taille de Paris, ed. by Michaëlsson, l'an 1297, p. 56 and 152.

63 'Ceratae Petri de Condeto Tabulae adversariorum modo ab anno MCCLXXXIV ad annum MCCLXXXVI conscriptae', in Recueil des historiens des Gaules et de la France, 22 (Paris: Imprimerie Impériale, 1865), pp. 468-501. "Guillelmus Scrimisse ad eadem dona, xx l.", p. 485 and "Guillelmus Escrimisse, ad equos hospicii Omnium Sanctorum, xviii l.", p. 492. 
and provosts of France in $1285 .{ }^{64}$ Richart l'escrémisseeur, Sanse l'escrémisseeur, Nicolas l'escremisseeur and Phelippe l'escremisseeur appeared only in the tax roll from 1292. Jacques l'escremisseeur and master Thomas l'escremisseeur appeared in three tax rolls: 1292, 1296 and 1297. It is worth mentioning that in the tax roll from 1313 there is no one called "escremisseeur" in any variation.

In publications dedicated to fencing ${ }^{65}$ have these examples been regularly presented as describing their job but this could also have been a nickname. For example, in the Tax Roll of 1297, there is a certain John the furrier, innkeeper (p. 57). Indeed, Michaëlsson explained that the surname given to the people in these rolls could take many forms, and sometimes was composed by two job names. In such case, the second normally referred to the working activity, but was it be possible to manage two different activities at the same time? Normally not at that time, except for the situation of seasonal work or sporadic activity which is less known. Michaëlsson clearly points out that it is difficult to know in that context if a forename based on a profession indicates a vocation or not. Therefore any statistical study based on the job names that appeared in these rolls can lead only to a provisional conclusion. ${ }^{66}$

This is the case for "Jacques l'escremisseur", who is explicitly named "weaver" in the tax roll from 1296, and was mentioned as early as 1291 in a city ordinance of Paris as the same. ${ }^{67}$ Here "l'escremisseeur" was most probably a nickname.

The case of master Thomas l'escremisseeur is problematic: the master title prefixed to his name differentiates him from all others. Michaëlsson states that the master title is more often placed in front of the designation of the profession. Unfortunately, he does not discuss the significance of its use before the first name. ${ }^{68}$ This is not rare, as there are more than a hundred of such prefixes in the tax roll of 1297. It seems to concern some activities like school teachers, doctors, lawyers, marshals, but also very wealthy people. ${ }^{69}$ It is then tempting to see in it a certain mark of distinction, but for Thomas

64 'Compotus ballivorum et prapositorum Francice anno Domini MCCXXXIV, mense Junio, de termino Ascensionis', in Recueil des historiens des Gaules et de la France, 22, p. 626.

65 For example in Daressy, pp. 127-28, in Anglo, p. 12, and in Brioist Pascal, 'L'invention de l'escrime moderne, de Rabelais à Montaigne', in Croiser le Fer, ed. by Brioist P., Drévillon H. Serna P. (Seyssel: Champ Vallon, 2002), p. 37.

66 Karl Michaëlsson, Études sur les noms de personne français d'après les rôles de la taille parisiens (Uppsala: Almquist \& Wiksells Boktryckeri, 1927) p. 24 note 1, p. 118 and p. 149.

67 "Nom des tesserranz. [...] Jacques le Scremisseeur". G.-B. Depping, ed., Règlemens sur les arts et métiers de Paris rédigés an XIIIe siècle et connus sous le nom du livre des métiers d'Étienne Boileau (Paris: Crapelet, 1837), pp. 402-04.

68 Michaëlsson, Études sur les noms de personne, pp. 154-55.

69 It is out of the scope of this article to publish the complete list but I propose a short sample: "Mestre Guillaume de reins, avocat VII E XV sous" p. 29, "Mestre Mabi de longueval, esmailleeur VII sous" p. 73, "Mestre Jehan pitart, mire LXX s.” p. 133, "Mestre Guillaume qui tient escole II sous" p. 262. 
l'escremisseeur, it is also possible that it was the way the fencing masters were qualified at that time. This will be discussed later.

How can this difference between each roll be explained? The one of 1292 is a general census and could be more complete than the other rolls. For example, perhaps the income of those people were below the minimum taxation level required to appear in the tax rolls of 1296 and 1297. Another option is that they changed their home location and lived at that time in an area that no longer depended on the city of Paris. As it may be, in the tax roll from 1313 there is no mention of any "escrimisseeur" or other variation. In conclusion, these tax rolls mostly provided onomastic information and are not a reliable way to count the number of active fencers. At least one person mentioned surely had a different job, and for the six others one cannot be certain that fencing was their vocation. Thus, one must exercise caution when making a reference to the "escrimisseeur" of Paris, or other sources.

\section{III.3. Early mentions of fencing masters}

In the previous paragraph, I discussed the case of Thomas l'escremisseeur from Paris. His name was formed by an expression that combines a title - that of a master followed by the first name and concluded by a vernacular word meaning fencers. There were some other examples to be found across Europe. The oldest version of such expression came from beyond the French-speaking area, in Cividale in Italy, and is dated from 1259: "master Goffredo 'schermitore". There is another example, "master Arnold 'scharmitor", mentioned in 1300 and 1307.70 The case of Master Roger le Skirmisour is even more famous. In 1311 he was sent to a prison in London for violating the local fencing regulations. ${ }^{71}$ And finally in 1319-1321, the archives from Lièges mention a certain master Weri l'Eskermisseur, recorded in Latin. ${ }^{72}$

Even if the number of known occurrences is low, this shows a consistency of the given expression from London all the way to the Northern Italy, be it written in French or in Latin. The temptation to interpret these expressions as a way to qualify fencing masters at that time - that is to say, someone whose main activity was to teach fencing - is obvious.

70 Fransceco Novati, ed., Il Fior di Battaglia, (Bergamo: Institute of Italian Graphic Arts, 1902) p. 18-19. Novati did not quote the original text, but I suspect them to be in Latin, probably something like "magister Goffredo schermitore".

71 'Un certain Roger le skirmisour, est accusé: eo quod tenet scholam de skirmeria de diversis hominibus et ad colligendos filios proborum bominum et bona patrum et matrum in malo usu et devastanda, ob quod ipsi mali homines devenerunt." Jules Delpit, Collection générale des documents français qui se trouvent en Angleterre, 1 (Paris: J. B. Dumoulin, 1847) p. Ixxxix. For an abstract in English, see Calendar of Letter-Books of the City of London: D, pp. 263-76 fol. cxxxiii.

72 "27 avril 1319. [...] presentibus magistro Werrico l'Eskermisseur [...]" and "25 mars 1321 Magister Werricus l'Eskermisieres, [...]”. Édouard Poncelet, Le livre des fiefs de l'église de Liége sous Adolphe de La Marck (Liège: Hayez, 1898), pp. 256-57 number 96 and 103. 
The situation remains unclear in the cases of individuals who do not bear the prefix master, but are said to be fencers without any ambiguity. Such is the case of "Roger de Shireburne, Skyrmisour" from London who was sent to prison in 1310 for having caused certain Gascon merchants injury by word or deed. ${ }^{73}$

\section{III.4. Early fencing regulation texts}

It is very rare to find regulations that explicitly mention fencing or fencers prior to the fourteenth century. This is why the following paragraph (extracted from a series of regulation documents from the aldermen of Hénin-Liétard) is exceptional, even if its dating remains indistinctly within the thirteenth century.

On fencers. No one, either burgher or aldermen should manage any throwing or fighting with any sharpened weapon one against another inside or outside the territory of the city under the fine of 60 shillings, and by banishment outside the city territory for one year and one day. ${ }^{74}$

The name "escremisseur" mentioned here leans more closely towards 'a duelist' rather than to someone skilled in the art of fencing. This may be a local particularity, yet it is an interesting one, as this association between fencers and duelists strongly reemerges during the second half of the sixteenth century.

Apart from the document cited above, other regulation texts come from London, one of the biggest towns in Europe at that time. The Book of Customs is supposed to have been composed around 1320, however, it is a compilation of older customs in use in London prior to that period. ${ }^{75}$ It contains an interesting text with the title The Punishment of Malefactors, which is partially concerned with the practice of fencing. It is worth noticing that this part of the Book of Customs is reproduced into the Letter Book D and could at least be dated before 1314:76

And also for those who delighted in bad behavior, go to learn fencing with the buckler inside the city, from night and day, and thanks to that enjoyed to do more bad actions, it is provided the following. No one can hold a school of fencing with the buckler, nor to learn it

\footnotetext{
73 Delpit, p. 43.

74 "Des escremisseurs. On fait le ban quil ne soit nus si hardis bourgois ne habitans keskievin aient â maniier ki giece ne escremisse de nule arme esmolue li uns a lautre dedens le pais de le vile ne debors sour le fourfait de LX $s$. et destre banis hors de le pais de le ville I an et un jour...". 'Charte communale, bans de l'échevinage, serments et coutumes d'Hénin-Liétard au XIIIe siècle', Recueil d'actes des XIIe et XIIIe siècles en langue romane wallonne du Nord de la France, ed. by Tailliar E. F. J. (Douai: Adam d’Aubers, 1849) p. 425 nº6.

75 Liber Albus, ed. by Riley H. T., Munimenta gildhallae londoniensis 1 (London: Longman, Brown, Green et al., 1859), p. xvi.

76 Calendar of Letter-Books of the City of London: D, 1309-1314, ed. by Sharpe R. R. (London, 1902), pp. 292-301.
} 
inside the city, night and day. And if someone does it, he gets jailed for 15 days. And he should not receive apprentices during the day, if he was not a man of good fame and renown; and if he does that and stand accused, it is the same sentence. ${ }^{77}$

Here fencing is seen as a way in which malefactors could prove even more annoying for the society. But what does a 'malefactor' mean in this context? A good example came from an incident that occurred inside the Great Hall of Westminster in the presence of the Justices in 1331. Five persons beat, wounded and maltreated a man using sword, dagger and buckler. ${ }^{78}$ Apparently, it was not a unique case, as during the judgment the "the King's attorney stated that certain other malefactors had committed the same transgression". The text explicitly mentioned the fencing with the buckler but no other set of weapons. That leads us to the question whether it was the only form of fencing existing there or was this the main type of fencing associated with civil circumstances? I am tempted to say that it is probably the latter, however, first one has to prove that other forms of fencing existed. Finally, there is an apparent paradox between forbidding the teaching of fencing, more accurately to hold school and to learn fencing, and the implicit authorization to receive apprentices during the day, if they were of good fame. What kind of school this text reffers to? As I explained in a article of mine, the term school often meant an open gathering of people practicing a specified activity. ${ }^{79}$ There probably were such schools, which were forbidden. However, another interpretation could be connected to the indication "inside the city". Could it imply that it was forbidden to hold school only in public areas within the city, but not in private? As I am not a specialist on London regulations, I am obliged to leave this question open.

This text does not seem to be the only one with such content. The Liber Alber contains an index of the Letter-Books (p. 640) with two references to fencing. The second was in the letter Book D and is titled "that no one hold a school at fencing with the buckler inside the city." As written before, it was a copy of the extract from the Book of Customs quoted above. The first was inside a block of articles that bear no date, in the Book $\mathrm{C}$ which is dated between 1291 and 1309. It asserted that "No one is to keep a

77 'Et ensement pur ceux qi se delitent de mesfere, vount aprendre de eskermir de bokeler deinz la cite, de noit et de jour, et pur ceo pluis senbaudissent de maufere, purveu est, qe nul tiegne escole, ne aprise, de eskymir de bokeler deinz la cite, de noit ne de jour. Et si nul le face, eit la prisoun xl jours. Et qe il ne resceive apprentiz de jour, sil ne soit home de bone fame et conu ; et sil face, et de ceo soit atteint, eist mesme la peine." Liber Albus, pp. 28283.

78 'Plea Rolls for Staffordshire: 5 Edward III', Staffordshire Historical Collections, ed. by Wrottesley G., Parker F., 11 (1890), pp. 21-35.

79 Dupuis Olivier, 'Organization and Regulation of Fencing in the Realm of France in the Renaissance', Acta Periodica Duellatorum, 2 (2014), pp. 233-35. 
fencing school by night or day, under pain of imprisonment for forty days." $" 80$ There is no other surviving contextual information. Strangely, Anglo referred to this text when he asserted than fencing was prohibited in London since 1189, but unless there is a more recent dating for this text that I might have overlooked, one must consider this assertion and this dating as a mistake. ${ }^{81}$

The older reference to such regulatory text was dated by Maitland from 1286:

That, whereas it was customary for such Profligates to learn the Art of Fencing, and were thereby emboldened to commit the most unheard of Villainies, no such School should be kept in the City for the future, upon the Penalty of forty Marks for every Offence. ${ }^{82}$

Strutt referred directly to this passage when he mentioned that "the masters and their scholars become so outrageous, that it was necessary for the legislature to interfere; and, in the fourteenth year of the reign of Edward I. (1286), an edict was published by royal authority, which prohibited the keeping of such schools, and the public exercise of sword and bucklers, 'eskirmer an bokeler." "83

One should note that Strutt certainly goes much further in his interpretation than what have been written by Maitland. The Fencing Masters have not been outrageous, and the Regulator only accused the malefactors of regularly study of fencing. Another point remains strange: Maitland did not mention the word buckler, so where does Strutt find it? Did he look directly at the source? The excerpt from Maitland took place inside a much broader text dedicated to the preserving of the Peace, apparently taken by Maitland from the Liber Horn, folio 272. Unfortunately, this manuscript compiled in 1311 has not received any complete edition so far. ${ }^{84}$ Egerton Castle did not refer to Maitland directly, but did use exactly the same wording "whereas it was customary for such Profligates..." showing that he certainly read Maitland. ${ }^{85}$ However, as with Strutt, Castle also added a reference to the sword and buckler and even quoted the same

80 Calendar of Letter-Books of the City of London: C, 1291-1309, ed. by Sharpe R. R. (London, 1901), pp. 15-20. The original text is partially transcript in the Liber Albus, p. 639: "Qe nul teigne Escole descerkermerye".

81 Anglo, Martial Arts of Renaissance Europe, p. 7 and 318 note 5.

82 William Maitland, The History and Survey of London from its Foundation to the Present Time, 1, (London: Osbone and Shipton, 1756), p. 106.

83 Joseph Strutt, The Sports and Pastimes of the People of England (London: Methuen \& Co, 1801), pp. 209-10.

84 Some extracts have been inserted into the first volume of the Statutes of the Realm, but there is nothing for the year 1286. See The Statutes: revised edition, 1 (London: Eyre and Spottiswoode, 1870).

85 Egerton Castle, Schools \& Masters of Fence from the Middle Ages to the Eighteenth Century (London: Bell and Sons, 1885), p. 16. 
French words "Eskirmer an Bokeler", which are missing in Maitland. Castle only referred to an enigmatic fifth edict of Edward I from 1286 for both quotes. Where does this mention of a buckler come from then? There should be either a missing document, or there has been a sort of confusion between the historical texts.

These regulation texts certainly had a direct result on the punishment of Master Roger le Skyrmisour in 1311 for having held a fencing-school. He was charged due to the participation of some sons of respectable families, which had inclined them to become bad men, but also, and probably, to waste the money of their family in such activities. ${ }^{86}$

\section{III.5. 3.5 From fencers to buckler players}

Fencing with the buckler was well established in England at the beginning of the fourteenth century. This form brushed off on every social level of the population, even the noblemen, as was illustrated by a Henry Burghersh. He had the reputation of being a skilled buckler player at the time he became the Bishop of Lincoln in 1320.87

There were also many occurrences of fencing with the buckler in German speaking areas, especially to be found in the literature from the thirteenth century. ${ }^{88}$ Among all the advice, decisions and rulings written by the rabbi Meir of Rothenburg during the thirteenth century, it is amazing to find one that referred to fencing with the shield or the buckler. It appeared in a compilation of "responsa", that is to say decisions and rulings delivered by the rabbi as answers to questions addressed to him:

About Ruben who pays Simon for teaching the art of the shield-bearer. After teaching him an entire day, he receives a salary equivalent to [a] plowman. But this art is different to the others because it permits to save people when bandits assail them. ${ }^{89}$

בעלי " The shield bearer mentioned here is a literal translation for "ba'alei terisin" or תריסין". It could represent the art of defense in general, but it most certainly refers to fencing with the sword and buckler.

86 'Un certain Roger le skirmisour, est accusé: eo quod tenet scholam de skirmeria de diversis hominibus et ad colligendos filios proborum hominum et bona patrum et matrum in malo usu et devastanda, ob quod ipsi mali bomines devenerunt." Delpit, p. lxxxix. For an abstract in English, see Calendar of Letter-Books of the City of London: D, pp. 263-76 fol. cxxxiii.

87 "..., dignitatem Lincolniensis ecclesiae Henrico de Borvassche adolescenti contulit, ad peltam praecipuo joculatori...”, Flores Historiarum, 1, ed. by Luard, Rolls Series 84 (London: Eyre and Spottiswoode, 1890) p. 192.

88 Kellett. 'Royal Armouries Ms I.33...', pp. 36-45.

89 Rabbi Meir's von Rothenburg bisher unedirte Responsen, ed. by Bloch Moses (Berlin: Mekize Nirdamim, 1891; repr. 1892), p. 285 \$335. The translation from the Hebrew have been done with the help of Guillaume de Sampaio. 
In comparison, we know of less information from the Realm of France and its satellite cultures in the continent. The epic poem Sone de Nansay from the end of the thirteenth century is a notable exception. It contains an priceless passage describing two duels with the buckler. I cannot resist presenting a large abstract of it.

During a banquet in a royal court, a certain Celos appeared without any armor but wearing two swords and two bucklers small enough to be hidden below his cloak (" $O t$ .II. bouclers et.II. espees / par dessous ses dras rechelees", v.15673-74). He took one sword and one buckler and threw some blows so skillfully that no bird could pass close to him without being touched ("Si gieta si menüement / Et faisoit entour lui aller / Que oisiaus n'i pëust voler / Que l'espee ne l'atainsist" v.15680-83). After this demonstration, he challenged the king that he could beat three of his men in a row with these weapons. The first to face him was the king's champion who, unfortunately for him, was said to know much more to fight with the shield than with the buckler ("il savoit petit dou boucler / mais as escus sot bien jeter" v.15727-28). He was defeated after only two attacks from his enemy, being touched first in his head, and then on his right arm. It was then the turn for Sone to face Celos. Sone carried his buckler in front of him and moved it in such a way that he was able to catch every attack of Celos. With his own blows, Sone gradually destroyed his opponent's buckler with his strikes. Fearing to lose his buckler, Celos tried to enter into wrestling but Sone prevented this action by opposing his buckler ("Sones sa volonté pierchoit / Que il viers lui venir voloit / Sones tient devant son boucler, Si ne puet chilz a lui aller" v.15893-96). Finally Sone found an opening and separed Celos' head from his body. This account is very interesting for many reasons. It is certainly one of the earliest mentions of a flourish with sword and buckler, if not the earliest. The fact that the champion of the king was not used to fighting with a buckler shows that, at least for the anonymous author, this required specific skills that could not be transferred easily from the common fighting skills with a large shield. The progressive deterioration of Celos' buckler seems to prove that he does not use his sword together with the buckler to manage the blows from Sone.

It is possible to find a similar fashion for this combination of the said weapons in archive documents from the fourteenth century. In Brittany, at the beginning of the fourteenth century, buckler play was associated with dice games in a book of local custom. It is recommended here to pay attention to certain types of people, including those who practiced dice games and buckler plays. ${ }^{90}$ It is surprising to see such activity mentioned beside the much more famous dice game.

90 "Car qui aprent à mauvès mestier chescun s'en devroit gaber, et les devroit l'en fuster, comme ceulx qui aprennent à mentir et à celer verité ou cas que besoign n'est, à renoier Dieu, la benoiste vierge Marie, les sainz. et les saintes, et avoer le deable et à si donner, à moquer et à degenner autres, et à jouer au jeu des diz et de bouclier, à resnours, batours, menaçeurs de gienz, despiteux, orgueilleux, pareçoux, luxurioux, envieux, glotonneux, convoitoux d'autruy." La très ancienne coutume de Bretagne, ed. by Planiol M. (Rennes: Plihorn et Hervé, 1896), p. 52. 
There is a record from 1346 to 1347 from the Archive of Besançon which lists usage fees from Jews living there. A certain Lyon Le Gros was simply mentioned as "master of the buckler" without any other indication. ${ }^{91}$ In this case, there is no context that could confirm that Lyon Le Gros was really a fencing master specialized in sword and buckler. Was he perhaps a master buckle maker? Probably not, as the common way to refer to such job was to call them master buckler and not master of the buckler. ${ }^{22}$ This expression strikes some similarities to the one previously described for the masters "escrimisseurs". But there the title is placed unambiguously in front of the name of the activity, as was typical for every type of weapon in the Realm of France during the following centuries until the end of the sixteenth century, as I demonstrated in a previous article. In this paper I propose a notion that during the fifteenth century and even a somewhat later, the custom was to speak about 'games' instead of 'fencing'. It is only during the sixteenth century that the technical documents preferred to use the French word "escrime" again. ${ }^{3}$

It is certainly very intriguing to note that there seems to have been a process taking place during the beginning of the fourteenth century, which completely modified the vocabulary, passing from fencing to buckler play, and from fencers to buckler players. It is possible that playing with the buckler was the main way to practice fencing for the commoners, if not the only one. If this suspicion is correct, it could explain why the buckler play became the common way to describe fencing in French at the end of the fourteenth century.

\section{CONCLUSION}

We can trace the development of fencing from the specific Old French technical vocabulary dedicated to this activity. In the beginning, it was only an action verb, an equivalent to the verb "to fence". Then a noun appeared in the twelfth century which took a much broader meaning. It was accompanied by a new set of technical vocabulary propagated with the help of oral traditions.

By a natural process, fencers appeared at the beginning of the thirteenth century separately from the traditional men-at-arms, the knights, guards or sergeants. Curiously, there are more references found in documents related to daily life than in the literature. Actually, the archive records show than most of the references are only surnames and not an occupational activity. However, this presents an important indication of

91 "Lyon Le Gros, maistre du boucler". Jules Gauthier, Inventaire sommaire des archives départementales antérieures à 1790. Doubs. Archives civiles, série B, chambre des comptes de Franche-Comté n 1 à 540 (Besançon: imprimerie Jacquin, 1883), p. 235.

92 "maistre bouclier". See for example this excerpt from the Book of Trades of Paris from 1268 "Quiconques soit mestre bouclier de laton[...] Li mestre bouclier et li vallet..." Depping, Règlemens sur les arts et métiers de Paris, p. 61.

93 Dupuis, 'Organization and Regulation of Fencing...' 
spreading of fencing as an activity that was associated with a certain amount of disorder. Around the turn of the thirteenth century, the city of London had already produced a handful of regulatory texts to try to limit fencing.

The question of the transmission of this knowledge remains largely open. Many French sources mention the study of fencing, managed by a master. However, for the period we have examined, the figure of the fencing master and its place inside medieval society could not be ascertained in this article.

\section{BIBLIOGRAPHY}

\section{V.1. Primary Literature}

Alexandriade ou chanson de geste d'Alexandre-le-Grand, ed. Le Court de la Villethassetz F., Talbot E. (Paris: Durand, 1861).

Aliscans, ed. by Wienbeck Erich et al. (Halle a.S.: Niemeyer, 1903).

Calendar of Letter-Books of the City of London: C, 1291-1309, ed. by Sharpe R. R. (London, 1901). <http://www.british-history.ac.uk/london-letter-books/volc> [accessed 21 December 2014]

Calendar of Letter-Books of the City of London: D, 1309-1314, ed. by Sharpe R. R. (London, 1902). <http://www.british-history.ac.uk/london-letter-books/vold> [accessed 21 December 2014]

'Ceratae Petri de Condeto Tabulae adversariorum modo ab anno MCCLXXXIV ad annum MCCLXXXVI conscriptae', in Recueil des historiens des Gaules et de la France, 22 (Paris: Imprimerie Impériale, 1865), pp. 468-501.

'Charte communale, bans de l'échevinage, serments et coutumes d'Hénin-Liétard au XIIIe siècle', Recueil d'actes des XIIe et XIIIe siècles en langue romane wallonne du Nord de la France, ed. by Tailliar Eugène François Joseph (Douai: Adam d'Aubers, 1849) pp. 387-454.

'Compotus ballivorum et præpositorum Francix anno Domini MCCXXXIV, mense Junio, de termino Ascensionis', in Recueil des bistoriens des Gaules et de la France, 22 (Paris: Imprimerie Impériale, 1865) pp. 623-72.

Curia Regis Rolls Preserved in the Public Record Office, 14 (1971).

Daurel et Beton, chanson de geste provençale, ed. Didot M. A., Meyer Paul (Paris: Firmin Didot, 1880).

Depping G.-B., ed., Règlemens sur les arts et métiers de Paris rédigés au XIIIe siècle et connus sous le nom du livre des métiers d'Étienne Boileau (Paris: Crapelet, 1837).

Eneas, ed. by Salverda de Grave Jacques (Halle: Niemeyer, 1891).

Esclarmonde, Clarisse et Florent, Y de et Olive: drei Fortsetzungen der Chanson von Huon de Bordeaux, ed. by Max Schweigel (Marburg: Elwert, 1889). 
Flores historiarum, ed. by Luard Henry Richards, 3 vols, Rolls Series 84 (London: Eyre and Spottiswoode, 1890).

Gaydon, ed. by Guessard F., Luce S. (Paris: Franck, 1862).

Géraud Hercule, ed., Paris sous Philippe-le-Bel d'après des documents originaux, et notamment d'après un manuscrit contenant le rôle de la Taille imposée sur les habitants de Paris en 1292 (Paris: imprimerie de Crapelet, 1837).

Hervis de Mes, Chanson de Geste Anonyme, ed. by Herbin J.-C. (Genève: Droz, 1992).

Hue de Rotelande, Protheselaus, ed. by Holden A. J., 3 vols (London: Anglo-Normand Text Society, 1991-1993).

Huon de Méry, Le Tournoiement de l'Antéchrist, ed. by Tarbé. P. (Reims: P. Regnier, 1851).

Jean Renart, L'Escoufle, roman d'aventure, ed. by Sweetser Franklin (Genève: Droz, 1974).

Joinville, Vie de Saint Louis, ed. by Monfrin Jacques (Paris: Dunod, 1995).

La chevalerie Ogier de Danemarche par Raimbert de Paris, ed. by Barrois J., 2 vol. (Paris: Techener, 1842).

La très ancienne coutume de Bretagne, avec les assises, constitutions de Parlement et Ordonnances ducales, ed. by Planiol Marcel (Rennes: Plihorn et Hervé, 1896).

L'art de chevalerie, traduction du De re militari de Végèce par Jean de Meun, ed. by Robert Ulysse, (Paris: Firmin Didot, 1897).

Le couronnement de Louis, chanson de geste du XIIe siècle, ed. by Ernest Langlois, 2nd ed., Les classiques français du Moyen Âge 22 (Paris: Champion, 1925).

Le Livre de la taille de Paris, l'an 1296, ed. by Karl Michaëlsson, Romanica Gothoburgensia 7 (Göteborg: Elanders boktryck, 1956).

Le Livre de la taille de Paris, l'an 1297, ed. by Karl Michaëlsson, Romanica Gothoburgensia 9 (Göteborg: Elanders boktryck, 1962).

Le Livre de la taille de Paris, l'an de grace 1313, ed. by Karl Michälsson, (Göteborg: Wettergren \& Kerbers förlag, 1951).

Le roman de Laurin, ed. by Thorpe Lewis (Cambridge: Heffer, 1958).

Le roman de Ponthus et Sidoine, ed. by Marie-Claude de Crécy (Genève: Droz, 1997).

Le Roman de Renart., ed. by Martin Edouard, 3 vol. (Strasbourg: K. J. Trübner, 18821887).

Le roman de Tristan en prose, éd. Curtis Renée, t. 2 (Leiden: Brill, 1976).

L'entree d'Espagne, chanson de geste franco-italienne publiée d'après le manuscrit unique de Venise, ed. by Thomas Antoine 2 vols (Paris: Firmin-Didot, 1913).

Les chartes des comtes de Saint-Pol (XIe-XIIIe siècles), ed. by Jean-François Nieus (Turnhout: Brepols, 2008).

Li fet des Romains compilé ensemble de Saluste et de Suetoine et de Lucan, ed. by Flutre L.-F., 2 vols. (Paris: Droz, 1935-1938). 
Liber Albus, ed. by Riley H. T., Munimenta Gildhallae Londoniensis 1 (London:

Longman, Brown, Green et al., 1859).

Maistre Wace's Roman de Rou et des ducs de Normandie, ed. by Andresen Hugo, 2 vols. (Heilbronn: Henninger, 1877-79).

Perceval le Gallois ou le Conte du Graal, ed. Potvin Ch., 6 vols. (Mons: DequesneMasquillier, 1866-1871).

'Plea Rolls for Staffordshire: 5 Edward III', Staffordshire Historical Collections, ed. by Wrottesley G., Parker F., 11 (1890) <http://www.british-history.ac.uk/staffs-histcollection/vol11> [accessed 21 December 2014].

Rabbi Meir's von Rothenburg bisher unedirte Responsen, ed. by Bloch Moses (Berlin: Mekize Nirdamim, 1891; repr. 1892)

Raoul de Cambrai, ed. by Meyer P., Longnon A. (Paris: Firmin Didot, 1882).

Raoul de Houdenc, Le songe d'enfer suivi de la Voie de paradis, ed. by Lebesgue Phileas (Paris: Sansot \& Cie, 1908).

Sone von Nausay, ed. by Moritz Goldschmidt (Tübingen: Litterarischer Verein in Stuttgart, 1899).

The Ancient English Romance of Havelock the Dane, Accompanied by the French Text, ed. by Madden F. (London: Nicol for the Roxburghe Club, 1828).

The Great Roll of the Pipe for the ninth year of the reign of King Richard the first Michaelmas 1197, ed. by Doris M. Stenton (London: Pipe Roll Society, 1931).

The Statutes: revised edition, 1 (London: Eyre and Spottiswoode, 1870).

Tristan, recueil de ce qui reste des poëmes relatifs à ses aventures composés en françois, en anglonormand et en grec dans les XII et XIIIe siècles, ed. by Michel Francisque (Paris: Techener, 1835).

\section{V.2. Secondary Literature}

Anglo Sydney, Martial Arts of Renaissance Europe (New Haven: Yale University Press, 2000).

Brioist Pascal, 'L'invention de l'escrime moderne, de Rabelais à Montaigne', in Croiser le Fer, ed. by Brioist P., Drévillon H. Serna P. (Seyssel: Champ Vallon, 2002), pp. $21-$ 70.

Castle Egerton, Schools \& Masters of Fence from the Middle Ages to the Eighteenth Century (London: Bell and Sons, 1885).

Cognot Fabrice, 'L'armement médiéval, les armes blanches dans les collections bourguignonnes, Xe-XVe siècles', (unpublished doctoral thesis, University Paris 1 Panthéon-Sorbonne, 2013). <http://www.theses.fr/2013PA010609> [verified 05/01/2015].

Daressy Henri, Archives des maîtres d'armes de Paris (Paris: maison Quantin, 1888). 
Dupuis Olivier, 'Organization and Regulation of Fencing in the Realm of France in the Renaissance', Acta Periodica Duellatorum, 2 (2014), pp. 233-254.

Förster W., 'Recensionen und anzeigen, Maistre Wace's Roman de Rou et des Ducs de Normandie', Zeitschrift für romanische Philologie, 1 (1877), pp. 144-159.

Gauthier Jules, Inventaire sommaire des archives départementales antérieures à 1790. Doubs. Archives civiles, série B, chambre des comptes de Franche-Comté $n^{\circ} 1$ à 540 (Besançon: imprimerie Jacquin, 1883).

Goldschmidt Moritz, 'Bruckner, Wilh., Charakteristik der germanischen Elemente im Italienischen', Zeitschrift für romanische Philologie, 24 (1900), pp. 574-578.

Green Richard Firth, 'Literature and Law', in A companion to Medieval English Literature and Culture c.1350-c.1500, ed. by Peter Brown, Blackwell companions to literature and culture 42 (Malden, MA: Wiley-Blackwell, 2009) pp. 292-306.

Jordan Leo, Über den altfranzösischen Abenteuerroman "Cristal et Clarie" (Bonn: Georgi, 1899).

Kellett Rachel E., 'Royal Armouries Ms I.33: The Judicial Combat and the Art of Fencing in Thirteenth- and Fourteenth-century German Literature', Oxford German Studies 41-1 (2013), pp. 32-56.

<http://www.maneyonline.com/doi/abs/10.1179/0078719112Z.0000000003> [accessed 18 January 2014]

Lewis R. E., Reidy J., Middle English Dictionary (The University of Michigan Press, 1998).

Maitland William, The History and Survey of London from its Foundation to the Present Time, 1 (London: Osbone and Shipton, 1756).

Michaëlsson Karl, Études sur les noms de personne français d'après les rôles de la taille parisiens, 1, Uppsala Universitets Årsskrift 4 (Uppsala: Almquist \& Wiksells Boktryckeri, 1927).

Mortureux Marie-Françoise, 'Les vocabulaires scientifiques et techniques', Les Carnets du Cediscor, 3 (1995), pp. 13-25. < http://cediscor.revues.org/463> [accessed 13 January 2015]

Novati Fransceco, ed., Il Fior di Battaglia, (Bergamo: Institute of Italian Graphic Arts, 1902).

Plouzeau May, 'Critique des éditions du roman des Eles et du Songe d'Enfer', in La structure de la proposition dans les langues romanes, ed. by Rouveret Alain, Sauzet Patrick (Revue des Langues Romanes, 93-1 (1989)), pp. 448-64.

Strutt Joseph, The Sports and Pastimes of the People of England (London: Methuen \& Co, 1801).

Trolli Domizio, 'Parole del Boiardo. Sul lessico e il testo dell'Inamoramento de Orlando', in Studi di storia della lingua italiana offerti a Ghino Ghinassi, ed. by Bongrani Paolo et al. (Firenze: Le Lettere, 2001), pp. 89-150.

Van Der Made Raoul, Inventaire analytique et chronologique du chartrier des Guillemins de Liège, 1317-1669 (Bruxelles: Palais des académies, 1955). 
Vieselovskiy Alexander Nicolaevich, Iz Istorii Romana i Povesti: Materijali i Isledovanija, 2 vols, (Saint Petersburg: Academy of Science, 1888). 